\title{
Shepherd Dawson, M.A., D.Sc.
}

By the sudden and unexpected death of Dr Shepherd Dawson, at the height of his powers, British psychology has suffered an irreparable loss. Born at Whitehaven, Cumberland, and educated at Owens College, Manchester, and King's College, London, Shepherd Dawson's main life-work was done in Glasgow, at the University and at Jordanhill Training College, but his influence in his science extended far beyond Glasgow. Though his main activities were involved in educational psychology, as principal Lecturer in Psychology, Logic, and Ethics at Jordanhill, Shepherd Dawson was recognised as one of the ablest experimental psychologists in the country, and his work on the frontiers between psychology and medicine must also be regarded as of the first importance. Articles in the British Journal of Psychology on the phenomena of binocular vision, particularly on phenomena of brightness and of colour-mixing, are models of their kind of work; the same may be said of articles in Archives of Diseases of Childhood on the influence on intelligence of encephalitis lethargica, epilepsy, etc.

During his period of work in London Shepherd Dawson studied statistics under Karl Pearson, and his interest in this field remained with him, and issued ultimately in the publication, in 1933, of his Introduction to the Computation of Statistics, a book which is quite invaluable for anyone who seeks to apply statistical methods to psychological and educational problems.

As an old and active member of the British Association-Secretary, Recorder, and, in 1934, President of Section J-Shepherd Dawson was widely known among men of science in this country; as Contributing Editor for Britain and the Colonies of the Psychological Index for many years, he was no less widely known in other countries. As a member of the Scottish Council for Research in Education since its institution, and as Convener of its Publications Committee and of its International Examinations Enquiry Committee, he has left a deep mark on contemporary educational and psychological science in Scotland.

A colleague of Shepherd Dawson's, writing to the author of the present notice, says of him: " $\mathrm{He}$ acted as a 'scientific conscience' to teams of research workers in a variety of problems connected with 
education, children's diseases, housing, and the like," and this "strict 'scientific conscience' has proved of incalculable value to research work in Scotland and may long serve as a standard for work in these fields." No estimate could be truer or juster.

He was elected a Fellow in $193 \mathrm{I}$, and died on March 26, 1935.

J. D. 